\title{
Biokeramik Hidroksiapatit (HAp) Berbahan Dasar Cangkang Tiram Anodonta nuttaliana dari Danau Poso
}

\section{Bioceramic Hydroxiapatite (HAp) Made From Anodonta nuttaliana Clams Shells fromPoso Lake}

\author{
Agung Rimayanto Gintu*1, Elizabeth Betty Elok Kristiani² dan Yohanes Martono ${ }^{3}$ \\ ${ }^{1}$ Magister Biologi, Fakultas Biologi, Universitas Kristen Satya Wacana, Jl. Diponegoro No. 52-60 Salatiga, Indonesia 50711 \\ ${ }^{2}$ Fakultas Bilogi, Universitas Kristen Satya Wacana, Jl. Diponegoro No. 52-60 Salatiga, Indonesia, 50711
}

${ }^{3}$ Fakultas Sains dan Matematika, Universitas Kristen Satya Wacana, Jl. Diponegoro No. 52-60 Salatiga, Indonesia, 50711

\section{Artikel histori : \\ Diterima 9 September 2020 \\ Diterima dalam revisi 8 Oktober 2020 \\ Diterima 28 Oktober 2020 \\ Online 31 Oktober 2020}

\begin{abstract}
ABSTRAK: Biokeramik Hidroksiapatit (HAp) merupakan suatu komponen kimiawi sintetik dari turunan kalsium fosfat yang umumnya digunakan untuk memperbaiki kerusakan jaringan keras. Biokeramik Hidroksiapatit dapat disintesis dari bahan-bahan yang kaya akan kalsium. Pada penelitian ini dilakukan sintesis dan karakterisasi fisikokima HAp dari cangkang tiram Anodonta nuttaliana yang diperoleh dari danau Poso, Sulawesi tengah. Dari hasil karakterisasi

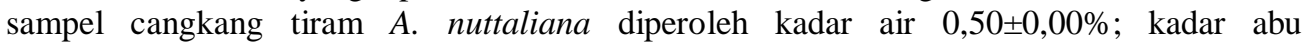

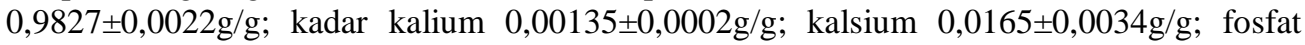
$0,1920 \pm 0,0424 \mathrm{~g} / \mathrm{g}$ dan rasio $\mathrm{Ca} / \mathrm{P} 1,9389 \pm 0,3039 \%$. Sintesis HAp dengan metode pengendapan basa menunjukkan yield sintesis sebesar 95,4320 $\pm 0,7085 \%$ dengan karakteristik HAp yang dihasilkan menunjukkan kadar kalium 0,0005 $\pm 0,00004 \mathrm{~g} / \mathrm{g}$; kalsium $0,9476 \pm 0,0012 \mathrm{~g} / \mathrm{g}$; fosfat $0,528 \pm 0,0075 ;$ rasio $\mathrm{Ca} / \mathrm{P} 1,0307 \pm 0,0932 \%$; porositas $73,9598 \pm 1,1320 \%$; daya kembang 9,6067 $\pm 2,5365 \%$; dan biodegradabilitas $8,8206 \pm 0,2176 \%$. Dari keseluruhan hasil disimpulkan bahwa cangkang tiram A. nuttaliana sangat potensial untuk dijadikan sumber biokeramik hidroksiapatit (HAp).
\end{abstract}

Kata Kunci: Biokeramik; Cangkang; Hidroksiapatit; Jaringan Keras.

ABSTRACT: Bioceramic Hydroxyapatite (HAp) was a derivated chemical synthetic compound from calcium phosphate commonly used to care the damage of hard tissues. Bioceramic Hydroxyapatite can synthetized from the compounds which rich with calcium contains. In this study threated the synthesis and physicochemical characterization to the HAp made from Anodonta nuttaliana clam shells obtained from Poso lake. From the characterization of the sample A. nuttaliana shells obtained the water contains $0,50 \pm 0,00 \%$; ash contains $0,9827 \pm 0,0022 \mathrm{~g} / \mathrm{g}$; potasium $0,00135 \pm 0,0002 \mathrm{~g} / \mathrm{g}$; calcium $0,0165 \pm 0,0034 \mathrm{~g} / \mathrm{g}$;

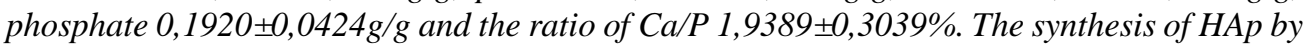
base precipitation method showed the yield of synthesis 95,4320 $\pm 0,7085 \%$ with the characteristic of the HAp showed that the potassium contains 0,0005 $\pm 0,00004 \mathrm{~g} / \mathrm{g}$; calcium $0,95476 \pm 0,0012 \mathrm{~g} / \mathrm{g}$; phosphate 0,528 $\pm 0,0075$; ratio of $\mathrm{Ca} / \mathrm{P} 1,0307 \pm 0,0932 \%$; porosity $73,9598 \pm 1,1320 \%$; swelling ability 9,6067 $\pm 2,5365 \%$; and biodegradability $8,8206 \pm 0,2176 \%$. From the overall results concluded that the A. nuttaliana clam shells was very potential to became a source of Bioceramic Hydroxyapatite (HAp).

Key Words: Bioceramics; Hydroxyapatit;, Hard Tissues; Shells 


\section{Pendahuluan}

Hidroksiapatit HAp merupakan komponen sintetik turunan kalsium dengan rumus kimia $\mathrm{Ca}_{10}\left(\mathrm{PO}_{4}\right)_{6}(\mathrm{OH})_{2}$ (Mittal et al, 2011); rasio Ca/P 1,67\%; densitas 3,19g/ml (Ferraz et al, 2004); simetri ruang $\mathrm{P}_{3} / \mathrm{m}$; parameter kisi $\mathrm{a}=9,432 \mathrm{~A}^{\mathrm{o}}, \mathrm{c}=6,875 \mathrm{~A}^{\circ}$ dan system kristalnya heksagonal (Kusrini dan Sontang, 2012 dalam Rachmania, 2012). HAp dapat disintesa dari komponen kaya kalsium dan umumnya komposit HAp digunakan untuk mereparasi tulang yang mengalami fraktura dan menambal gigi yang berlubang (Amrina, 2008). Struktur kimia HAp ditunjukkan pada Gambar 1.

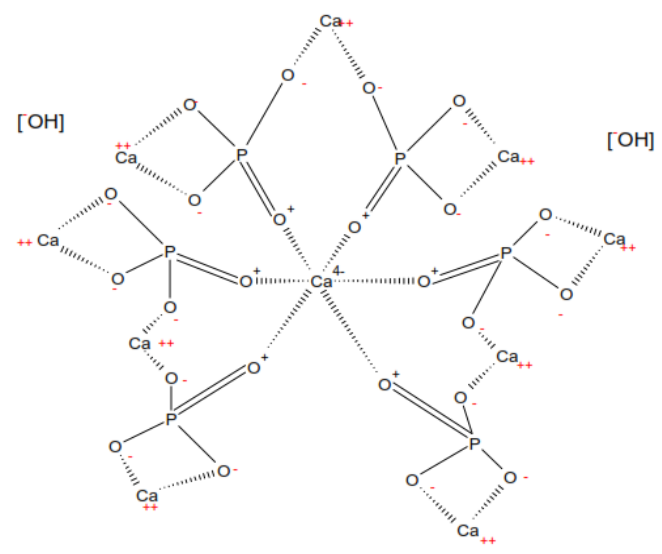

Gambar 1. Struktur Kimia HAp (Agrawal et al, 2011; Elkayar et al, 2009)

Struktur kimia HAp berpotensi sebagai komponen remineralisasi jaringan keras karena memiliki kesamaan struktur dengan kalsium penyusun tulang (Amrina, 2008). HAp sangat popular di dunia medis terutama reparasi tulang karena sifatnya yang biocompatible dan dapat menggantikan pen (platina) dalam penanganan fraktura tulang (Ramli et al, 2011). Beberapa penelitian sintesis HAp sebelumnya di Indonesia menggunakan bahan kerabang telur dan cangkang Mollusca menunjukkan hasil dan korelasi hasil yang positif (Affandi et al, 2015; Amrina, 2008; Fitri, 2014; Gintu et al, 2017a).

Penelitian sebelumnya di Indonesia menggunakan beberapa sumber yaitu: tulang sapi (Wahdah et al, 2014), cangkang Mollusca (Affandi et al, 2015; Fitri, 2014), kerabang telur (Gintu et al, 2017a; Mahreni et al, 2012; Wadu et al, 2017), ion kalsium dan fosfat dalam membran selulosa bacterial (Windarti dan Yayuk, 2006) dan kalsit (Prabaningtyas, 2015).

Cangkang Mollusca juga dapat dijadikan sumber HAp karena memiliki kandungan kalsium yang lebih tinggi daripada kerabang telur (Affandi et al, 2015; Fitri, 2014). Pada proses sintesis HAp dari cangkang Mollusca terjadi reaksi kimia pada persamaan 1 (Ningsih et al, 2014).

$10 \mathrm{CaO}+6\left(\mathrm{NH}_{4}\right)_{2} \mathrm{H}_{3} \mathrm{PO}_{4}+2 \mathrm{H}_{2} \mathrm{O} \rightarrow \mathrm{Ca}_{10}\left(\mathrm{PO}_{4}\right)_{6}(\mathrm{OH})_{2} \downarrow+$ $12 \mathrm{NH}_{4} \mathrm{OH}$
Penelitian oleh Ningsih et al (2014) yang melakukan sintesis HAp dari cangkang kerang kepah (polymesoda erosa) melaporkan bahwa semakin lama waktu pengadukan, semakin besar presentase HAp yang dihasilkan. Hasil Sintesis HAp oleh Ningsih et al (2014) ditampilkan pada Tabel 1.

Tabel 1. Sintesis HAp dari Cangkang Kerang Kepah dengan Variasi Waktu Pengadukan (Ningsih et al, 2014)

\begin{tabular}{cc}
\hline Waktu Pengadukan (Menit) & $\begin{array}{c}\text { Presentase HAp } \\
(\% \mathrm{w} / \mathrm{w})\end{array}$ \\
\hline 30 & 53 \\
\hline 60 & 60 \\
\hline 90 & 71 \\
\hline
\end{tabular}

Penggunaan cangkang kerang sebagai sumber HAp digagaskan karena kelimpahan di Indonesia sangat potensial yaitu sebesar 34.929 ton per tahun dimana kerang darah merupakan komoditas utama (Affandi et al, 2015). Komposisi mineral penyusun cangkang kerang darah ditampilkan pada Tabel 2.

Tabel 2. Komposisi Mineral Penyusun Cangkang Kerang Darah (Anadara granosa) (Awang-Hazmi, 2007 dalam Khoirudin et al, 2015)

\begin{tabular}{ll}
\hline Komponen & Kandungan (\% Berat) \\
\hline $\mathrm{CaCO}_{3}$ & 98,7 \\
\hline $\mathrm{Na}$ & 0,9 \\
\hline $\mathrm{P}$ & 0,02 \\
\hline $\mathrm{Mg}$ & 0,05 \\
\hline $\mathrm{Fe}, \mathrm{Cu}, \mathrm{Ni}, \mathrm{B}, \mathrm{Zn}$ dan $\mathrm{Si}$ & 0,2 \\
\hline
\end{tabular}

Di negara Indonesia HAp umumnya digunakan untuk mejadi biokeramik untuk meng-implant jaringan keras yang rusak (gigi dan tulang) (Rahmawati et al, 2012) karena menurut Amrina (2008) dan Nurmata et al (2014), butuh komposit yang memiliki kesamaan struktur dengan tulang untuk mereparasi dan remineralisasi tulang. HAp sendiri tersusun atas kalsium dan fosfat yang mirip penyusun tulang sehingga sangat memungkinkan untuk dijadikan bahan remineralisasi dan reparasi jaringan keras (Gintu et al, 2017a; Wadu et al, 2017). Sintesis material untuk keperluan bone graft, bone filer dan bone implant berbasis HAp didasari oleh kebutuhan akan donor tulang yang terbatas namun banyak yang membutuhkan (Nurmata et al, 2014; Susanto et al, 2014). Contohnya, Rumah Sakit Doktor Soetomo Surabaya setiap bulannya menangani 300-400 kasus bedah tulang sehingga memicu kenaikan permintaan material implant tulang (Gunawan et al, 2010 dalam Susanto et al, 2014). Selain itu, Indonesia juga adalah negara dengan jumlah penderita patah tulang terbanyak se-Asia (Susanto et al, 2014). Tujuan dari penelitian ini adalah menghasilkan sediaan biokeramik Hidroksiapatit (HAp) yang disintesis dari cangkang Tiram Mutiara (Anodonta nuttaliana) air tawar dari Danau Poso untuk keperluan remineralisasi dan reparasi jaringan keras. 


\section{Metode Penelitian}

\subsection{Waktu dan Tempat Penelitian}

Waktu pengambilan sampel cangkang tiram A. nuttaliana dilakukan pada bulan Juli-Agustus 2018 di daerah pinggiran Danau Poso dalam area Kota Wisata Tentena hingga Kawasan Wisata Siuri $( \pm 28 \mathrm{Km}$ sepanjang tepian Danau). Analisis dan sintesis HAp dilakukan di Laboratorium Fakultas Biologi dan Fakultas Sains dan Matematika, Universitas Kristen Satya Wacana Salatiga, Jawa Tengah. Waktu analisis dan sintesis dilakukan pada September - Desember 2018 hingga Januari 2019.

\subsection{Karakterisasi Sampel Cangkang Tiram $A$. nuttaliana}

Kadar Air, Abu, Bahan Organik, Karbon, dan Silikon Pengukuran Kadar Air, Abu, Bahan Organik, Karbon, dan Silikon dilakukan dengan metode grafimetrik (Sulaeman dkk, 2005).

\section{Kadar Fosfor dan Sulfat}

Kadar Fosfor diukur secara spektrofotometrik pada $\lambda$ $860 \mathrm{~nm}$ menggunakan pereaksi Molybdat-Ascorbat (Bray) mengacu pada Sulaeman dkk (2005), dan menggunakan pereaksi Molybdat-Vanadat pada $\lambda$ 880nm menggunakan Hach Fotometer (angka 490 dan 496).

Kadar sulfat diukur dengan pereaksi yang sama namun dilakukan pada $\lambda 620 \mathrm{~nm}$ (Sulaeman et al, 2005)

\section{Kalium}

Pengukuran Kadar Kalium menggunakan pereaksi $\mathrm{HNO}_{3}$ pekat dan $10 \mathrm{HClO}_{4}$ pekat lalu diukur menggunakan fotometer nyala (Flame photometer) (Sulaeman et al, 2005)

\section{Kadar Kalsium}

Pengukuran kadar kalsium (Ca) secara spektrofotometrik menggunakan pereaksi mureksid pada $\lambda 515 \mathrm{~nm}$ mengacu pada Rahayu et al (2011)

\footnotetext{
Sintesis Biokeramik Hidroksiapatit (HAp) dari Cangkang Tiram A. nuttaliana

Sintesis biokeramik HAp dari cangkang tiram mutiara (Anodonta nuttaliana) air tawar dari Danau Poso menggunakan metode pengendapan basa. Cangkang dilarutkan dalam $\mathrm{HCl}$ pekat dengan rasio 1:10 w/v, setelah larut ditambahkan $\mathrm{NH}_{3}$ (PA) hingga $\mathrm{pH}$ 9,5. Setelah $\mathrm{pH}$ mencapai 9,5 dilakukan penambahan pereaksi $\mathrm{KH}_{2} \mathrm{PO}_{4}$ $0,8 \mathrm{M}$ hingga endapan berhenti terbentuk (larutan jenuh). Endapan yang dihasilkan dipisahkan dari larutan kemudian dilarutkan lagi dengan $\mathrm{HCl}$ pekat hingga $\mathrm{pH} 1$ lalu di sintering pada suhu $70^{\circ} \mathrm{C}$ selama 2 jamhingga terbentuk endapan Brushite. Endapan brushite selanjutnya dipijar pada suhu $200^{\circ} \mathrm{C}$ selama 2 jam dilanjutkan pada suhu $1000^{\circ} \mathrm{C}$ selama 5 jamlalu diperoleh padatan Kristal putih HAp (Mittal et al, 2011).
}

Karakterisasi Biokeramik Hidroksiapatit (HAp) dari Cangkang Tiram A. nuttaliana

Kadar Kalium

Pengukuran Kadar Kalium menggunakan pereaksi $\mathrm{HNO}_{3}$ pekat dan $10 \mathrm{HClO}_{4}$ pekat lalu diukur menggunakan fotometer nyala (Flame photometer) (Sulaeman et al, 2005)

\section{Fosfor dan Sulfat}

Kadar Fosfor diukur secara spektrofotometrik pada $\lambda$ $860 \mathrm{~nm}$ menggunakan pereaksi Molybdat-Ascorbat (Bray) mengacu pada Sulaeman dkk (2005), dan menggunakan pereaksi Molybdat-Vanadat pada $\lambda 880 \mathrm{~nm}$ menggunakan Hach Fotometer (angka 490 dan 496)

Kadar sulfat diukur dengan pereaksi yang sama namun dilakukan pada $\lambda 620 \mathrm{~nm}$ (Sulaeman et al, 2005)

\section{Kadar Kalsium}

Pengukuran kadar kalsium $(\mathrm{Ca})$ secara spektrofotometrik mengacu pada Rahayu et al (2011).

\section{Karakterisasi Biokimiawi HAp}

Karakterisasi biokimiawi HAp hasil sintesis dari cangkang tiram A. nuttaliana meliputi pengukuran Porositas, Biodegradabilitas dan Daya Kembang dengan metode grafimetrik dan maserasi dalam larutan campuran aquades, etanol dan buffer $\mathrm{PO}_{4}$ mengacu pada Wahl \& Czernuszka (2006); Wattanutchariya \& Whattanapong (2014); Gintu et al (2017b).

\section{Hasil dan Pembahasan (Result and Disscussion)}

Tiram A. nuttaliana merupakan salah satu jenis Mollusca penghuni danau Poso sehingga sangat mudah menemukan cangkan tiram ini (yang sudah kosong) di sepanjang pinggiran danau Poso yang berpasir. Cangkang-cangkang tersebut berserakan seperti kodisi di pinggir laut dan tidak digunakan atau dimanfaatkan lagi. Cangkang-cangkang tiram A. nuttaliana berpotensi sebagai sumber HAp karena kaya akan kalsium $(\mathrm{Ca})$ dan fosfor $\left(\mathrm{PO}_{4}\right)$ seperti cangkangcangkang Mollusca pada umumnya.

Komponen kalsium dan fosfor meripakan bahan (atomic) penyusun struktur kimia HAp. Sebelum cangkang tiram $A$. nuttaliana dikarakterisasi, dilakukan klasifikasi taksonomi. Taksonomi tiram Anodonta nuttaliana ditampilkan pada Gambar 2.

Karakterisasi kimiawi terhadap cangkang tiram A. nuttaliana dilakukan untuk memperkuat dugaan atau prakira yang memperkirakan bahwa cangkang tiram A. nuttaliana berpotensi sebagai sumber HAp karena kaya akan mineral penyusun struktur kimiawi HAp terutama kalsium (Ca) dan Fosfor (P). 
membentuk HAp (terikat dalam struktur Kristal) sementara Ca yang diluar struktur HAp terpijarkan. Ca dalam struktur tidak terpijarkan karena energi ikat antara $\mathrm{Ca}, \mathrm{P}$ dan $\mathrm{O}$ dalam HAp cukup kuat untuk menahan energi pada suhu $1000^{\circ} \mathrm{C}$ (Yakin, 2013). Pada pengukuran kadar Ca, pengukuran dilakukan 2 kali menggunakan metode berbeda yaitu titrimetric dan spektrofotometrik.

Tabel 4. Hasil Karakterisasi Biokeramik Hidroksiapatit (HAp) dari Cangkang Tiram A. nuttaliana

\begin{tabular}{|c|c|c|c|}
\hline Metode & Parameter Sintesis & Satuan & Hasil \\
\hline \multirow[t]{3}{*}{ Grafimetrik } & Rendemen & $\%$ & $4,5680 \pm 0,7085$ \\
\hline & Yield & $\%$ & $95,4320 \pm 0,7085$ \\
\hline & Kadar Mineral & & \\
\hline Titrimetrik & Kalsium $(\mathrm{Ca})$ & $\mathrm{g} / \mathrm{g}$ & $0.0197 \pm 0,0001$ \\
\hline \multirow{11}{*}{$\begin{array}{l}\text { Spektrofoto } \\
\text { metrik }\end{array}$} & Kalsium (Ca) & $g / g$ & $0,9479 \pm 0,0011$ \\
\hline & Sulfat $\left(\mathrm{SO}_{4}\right)$ & $\mathrm{g} / \mathrm{g}$ & $0,0040 \pm 0,0003$ \\
\hline & Kalium $(\mathrm{K})$ & $g / g$ & $0,0005 \pm 0,00004$ \\
\hline & Fosfat $\left(\mathrm{PO}_{4}\right)$ & $\mathrm{g} / \mathrm{g}$ & $0,5283 \pm 0,0075$ \\
\hline & $\mathrm{P}_{2} \mathrm{O}_{5}$ & $\mathrm{~g} / \mathrm{g}$ & $0,084 \pm 0,0012$ \\
\hline & $\mathrm{P}_{2} \mathrm{O}_{5}$ Larut & $\mathrm{g} / \mathrm{g}$ & $0,040 \pm 0,0006$ \\
\hline & $\mathrm{P}_{2} \mathrm{O}_{5}$ Total & $\mathrm{g} / \mathrm{g}$ & $0,1221 \pm 0,0017$ \\
\hline & Fosfor (P) Terlarut & $g / g$ & $0,0053 \pm 0,0008$ \\
\hline & Fosfor $(\mathrm{P})$ Total & $\mathrm{g} / \mathrm{g}$ & $0,2641 \pm 0,0038$ \\
\hline & Rasio Ca/P* & $\%$ & $1,0307 \pm 0,0932$ \\
\hline & Fosfat $\left(\mathrm{PO}_{4}\right)$ & $\frac{\text { massa }}{\mathrm{g} / \mathrm{g}}$ & $0,133 \pm 0,00006$ \\
\hline \multirow{5}{*}{$\begin{array}{c}\mathrm{HACH} \\
\text { Fotometer }\end{array}$} & $\mathrm{P}_{2} \mathrm{O}_{5}$ & $\mathrm{~g} / \mathrm{g}$ & $0,0991 \pm 0,00006$ \\
\hline & $\begin{array}{c}\text { Total Fosfor (P) } \\
\quad(490)\end{array}$ & $g / g$ & $0,44 \pm 0,00003$ \\
\hline & $\begin{array}{c}\text { Total Fosfor (P) } \\
\text { (496) }\end{array}$ & $\mathrm{g} / \mathrm{g}$ & $0,35 \pm 0,00007$ \\
\hline & Rasio $\mathrm{Ca} / \mathrm{P}^{* *}$ & $\begin{array}{c}\% \\
\text { massa } \\
\end{array}$ & $0,96 \pm 0,02$ \\
\hline & $\begin{array}{c}\text { Parameter } \\
\text { Biokimia }\end{array}$ & & \\
\hline \multirow[t]{4}{*}{ Grafimetrik } & Porositas & $\%$ & $73,9598 \pm 1,1320$ \\
\hline & Biodegradabilitas & $\%$ & $8,8206 \pm 0,2176$ \\
\hline & Daya Kembang & $\%$ & $9,6067 \pm 2,5365$ \\
\hline & $\begin{array}{c}\text { Pengamatan } \\
\text { Kualitatif }\end{array}$ & & \\
\hline \multirow{3}{*}{$\begin{array}{l}\text { Pengindraa } \\
n \text { Langsung }\end{array}$} & Tekstur & - & Agak Kasar \\
\hline & Bentuk & - & Butiran/Serpihan \\
\hline & Warna & - & Abu-abu Pudar \\
\hline
\end{tabular}

* Rasio $\mathrm{Ca} / \mathrm{P}$ berdasarkan kadar $\mathrm{P}$ yangterukur menggunakan metode Bray dengan pereaksi Molybdat-Askorbat menggunakan Spektrofotometer

** Rasio $\mathrm{Ca} / \mathrm{P}$ berdasarkan kadar $\mathrm{P}$ yangterukur menggunakan metode Olsen dengan pereaksi Molybdat-Vanadat (Blue Molybdat) menggunakan Hach Fotometer

Hasil pengukuran metode titrimetric menunjukkan kadar Ca yang lebih besar karena menggunakan pereaksi EDTA yang juga dapat bereaksi dengan $\mathrm{Mg}$ sehingga kadar $\mathrm{Ca}$ yang diperoleh bukanlah angka kadar Ca sesungguhnya melainkan angka kandungan sadah (campuran $\mathrm{Ca}$ dan $\mathrm{Mg}$ ) (Sulaeman et al, 2005). Sementara kadar yang diperoleh dari metode spektrofotometrik pada $\lambda \quad 515 \mathrm{~nm}$ menggunakan pereaksi Mureksid menunjukkan kadar $\mathrm{Ca}$ sebagai $\mathrm{CaCO}_{3}$ (spesifik) (Rahayu et al, 2011) sehingga terukur lebih kecil dari hasil metode titrimetrik.
Parameter lain untuk karakterisasi HAp adalah dengan mengukur perbandingan kalsium terhadap fosfor (Rasio $\mathrm{Ca} / \mathrm{P})$. Perbandingan jumlah Rasio $\mathrm{Ca} / \mathrm{P}$ dari penelitianpenelitian sebelumnya dibandingkan dengan HAp hasil sintesis dari cangkang tiram $A$. nuttaliana ditampilkan pada Tabel 5.

Tabel 5. Perbandingan Rasio Ca/P HAp hasil Sintesis dari Cangkang Tiram A. nuttaliana terhadap Penelitian Sebelumnya yang dijadikan Acuan.

\begin{tabular}{|c|c|c|c|c|}
\hline \multirow{2}{*}{$\begin{array}{l}\text { Para } \\
\text { meter }\end{array}$} & \multirow{2}{*}{$\begin{array}{c}\text { HAp } \\
\text { Cangkang } \\
\text { Tiram } A . \\
\text { nuttaliana }\end{array}$} & \multicolumn{3}{|c|}{ Penelitian Sebelumnya } \\
\hline & & $\begin{array}{l}\text { Wadu et } \\
\text { al (2017) }\end{array}$ & $\begin{array}{c}\text { Nurmata et } \\
\text { al (2014) }\end{array}$ & $\begin{array}{c}\text { Windarti \& } \\
\text { Yayuk } \\
(2006)\end{array}$ \\
\hline Rasio & $1,0307 \pm$ & $1,07 \%$ & $1,66 \%$ & $1,6760 \%$ \\
\hline $\mathrm{Ca} / \mathrm{P}$ & 0,0932 & $1,06 \%$ & $1,74 \%$ & $1,8209 \%$ \\
\hline$(\%$ & (Bray) & & $1,88 \%$ & $0,0433 \%$ \\
\hline mass & & & $1,78 \%$ & $0,0599 \%$ \\
\hline a) & $\begin{array}{c}0,96 \pm \\
0,02 \\
\text { (Olsen) }\end{array}$ & & & $0,0423 \%$ \\
\hline
\end{tabular}

Rasio $\mathrm{Ca} / \mathrm{P}$ pada HAp dalam penelitian ini menunjukkan hasil yang mendekati penelitian-penelitian sebelumnya, menunjukkan bahwa HAp yang diperoleh dari sintesis dapat disetarakan dengan hasil-hasil penelitian lain yang menjadi acuan. HAp hasil sintesis dari cangkang tiram $A$. nuttaliana ditampilkan pada Gambar 3.

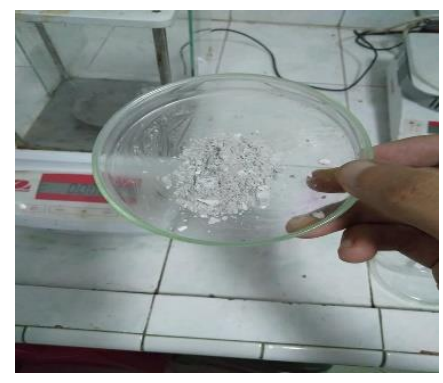

Gambar 3. Biokeramik HAp Hasil Sintesis dari Cangkang Tiram Anodonta nuttaliana (Dokumentasi Pribadi Penulis)

Warna HAp yang dihasilkan tidak putih sepenuhnya seperti yang di laporkan oleh penelitian-penelitian sebelumnya. HAp yang dihasilkan pada penelitian ini berwarna putih abu-abu karena adanya kandungan belerang dari sampel cangkan tiram yang masih menempel pada HAp setelah di sintesis. Kandungan belerang (S) yang masih terkandung dalam HAp adalah sebesar $0,0040 \pm 0,0003 \mathrm{~g} / \mathrm{g}$.

Selanjutnya dilakukan karakterisasi biokimiawi untuk melakukan standarisasi dengan parameter medis dengan tujuan mengetahui sifat-sifat biokimiawi HAp sebelum diaplikasikan. Karakterisasi biokimiawi meliputi pengukuran Porositas, Biodegradabilitas, dan Daya Kembang. Perbandingan porositas HAp dari penelitianpenelitian sebelumnya dibandingkan dengan HAp hasil 
sintesis dari cangkang tiram $A$. nuttaliana ditampilkan pada Tabel 6.

Tabel 6. Perbandingan Porositas HAp hasil Sintesis dari Cangkang Tiram A. nuttaliana terhadap Penelitian Sebelumnya yang dijadikan Acuan

\begin{tabular}{|c|c|c|c|}
\hline \multirow[t]{2}{*}{ Parameter } & \multirow{2}{*}{$\begin{array}{c}\text { HAp } \\
\text { Cangkang } \\
\text { Tiram A. } \\
\text { nuttaliana }\end{array}$} & \multicolumn{2}{|c|}{ Penelitian Sebelumnya } \\
\hline & & $\begin{array}{c}\text { Nurmata } \\
\text { et al } \\
(2014)\end{array}$ & $\begin{array}{c}\text { Gintu et } \\
\text { al } \\
(2017 b)\end{array}$ \\
\hline \multirow{4}{*}{$\begin{array}{c}\text { Porositas } \\
(\%)\end{array}$} & \multirow{4}{*}{$\begin{array}{c}73,9598 \pm \\
1,1320\end{array}$} & 88,442 & \multirow{4}{*}{$\begin{array}{c}63,7476 \\
\pm \\
5,79145\end{array}$} \\
\hline & & 84,890 & \\
\hline & & 74,830 & \\
\hline & & 63,906 & \\
\hline
\end{tabular}

Porositas menunjukkan kemampuan Biokeramik HAp membentuk pori. Pembentukan pori berfungsi untuk tempat terbentuknya sel jaringan keras yang baru saat HAp diaplikasikan sebagai agen remineralisasi jaringan keras. Parameter Biodegradabilitas berfungsi menunjukkan perhitungan pendekatan tingkat keteruraian HAp jika diaplikasikan dalam tubuh makhluk hidup (terutama manusia) untuk mereparasi jaringan keras yang mengalami kerusakan. Biodegradabilitas HAp hasil sintesis dari cangkang tiram $A$. nuttaliana menunjukkan hasil pengukuran sebesar $8,8206 \pm 0,2176 \%$, lebih rendah dari hasil penelitian sebelumnya oleh Gintu et al (2017b) yang menunjukkan biodegradabilitas sebesar 27,8833 \pm $0,46448 \%$, presentase biodegradabilitas pada kisaran ini masih tergolong aman karena jika biodegradabilitas terlalu besar maka struktur HAp akan rapuh ketika diaplikasikan (Wahl \& Czernuszka, 2006; Wattanutchariya \& Whattanapong, 2014; Gintu et al, 2017b).

Pengukuran daya kembang bertujuan sebagai patokan pendekatan biokimiawi terhadap HAp jika diaplikasikan kepada makhluk hidup apakah HAp akan mengalami pemuaian massa dan volume ketika bereaksi dengan senyawa kimia dalam tubuh. Jika HAp yang dihasilkan sangat tanggap terhadap reaksi kimia maka daya kembangnya akan besar sehingga strukturnya akan melemah ketika diaplikasikan untuk memperbaiki jaringan keras. Daya kembang HAp yang dihasilkan dari penelitian ini sebesar 9,6067 $\pm 2,5365 \%$ per 7x24 jam; lebih kecil dari hasil penelitian sebelumnya oleh Gintu et al (2017b) yang melaporkan bahwa daya kembang biokeramik HAp sebesar $10,9983 \pm 7,36003 \%$ per $7 \times 24$ jam. Jika daya kembang terlalu besar, biokeramik akan rawan mengalami pemuaian terutama volume ketika terpapar reaksi kimia dalam tubuh.

Secara keseluruhan, semua parameter uji dalam karakterisasi biokimiawi HAp berfungsi sebagai pendekatan untuk memperkirakan perubahan kondisi HAp setelah diaplikasikan kedalam tubuh makhluk hidup terutama untuk remineralisasi jaringan keras, atau dijadikan landasan keilmuan untuk tujuan pengembangan gagasan remineralisasi atau reparasi jaringan keras kedepannya. Perlu dilakukan karakterisasi struktur Kristal HAp hasil sintesis, parameter yang paling standar yang disarankan adalah analisis FTIR dan XRD. Jika gagasan atau penelitian masih tetap akan dilanjutkan maka perlu karakterisasi lanjutan juga menggunakan instrument SEM dan TEM.

\section{Kesimpulan}

Cangkang tiram Anodonta nuttaliana berpotensi sebagai sumber biokeramik Hidroksiapatit (HAp) karena mengandung Kalsium (Ca) sebesar 0,0165 $\pm 0,0034 \mathrm{~g} / \mathrm{g}$ dan Fosfor $(\mathrm{P})$ sebesar $0,0960 \pm 0,0212 \mathrm{~g} / \mathrm{g}$; Rasio $\mathrm{Ca} / \mathrm{P}$ sebesar $1,9389 \pm 0,3039 \%(\mathrm{w} / \mathrm{w})$. Proses sintesis HAp dari cangkang tiram $A$. nuttaliana menggunakan metode Pengendapan Basa dengan suhu pemijaran $900^{\circ} \mathrm{C}$. Hasil sintesis HAp dari cangkang tiram A. nuttaliana menunjukkan tingkat potensi keberhasilan sintesis HAp sebesar 95,4320 $\pm 0,7085 \%$ dengan tingkat reduksi material selama sintesis sebesar 4,5680 $\pm 0,7085 \%$; sediaan HAp yang diperoleh berbentuk butiran berwarna abu-abu dengan kadar Kalsium $(\mathrm{Ca})$ sebesar $0,0095 \pm 0,0011 \mathrm{~g} / \mathrm{g}$; kadar Fosfor $(\mathrm{P})$ sebesar $0,0264 \pm 0,0038 \mathrm{~g} / \mathrm{g}$; Rasio $\mathrm{Ca} / \mathrm{P}$ sebesar 1,0307 $\pm 0,0932 \%$, Porositas sebesar 73,9598 \pm $1,1320 \%(\mathrm{w} / \mathrm{w})$; Biodegradabilitas sebesar 8,8206 \pm 0,2176\% (w/w) dan Daya Kembang sebesar 9,6067 \pm $2,5365 \%$ per $7 \times 24$ jam. Proses karakterisasi bertujuan untuk melakukan penyetaraan HAp terhadap acuan-acuan yang dijadikan standar tolok ukur agar bukti dari hasil karakterisasi dapat dijadikan landasan aplikasi atau pengembangan gagasan kedepannya. Berdasarkan hasil karakterisasi dapat disimpulkan bahwa HAp hasil sintesis dari cangkang tiram $A$. nuttaliana berpotensi untuk diaplikasikan sebagai suatu komponen remineralisasi jaringan keras.

\section{Ucapan Terima kasih}

Ucapan terimakasih diucapkan kepada lembaga Prodi Magister Biologi, Fakultas Biologi dan Prodi Kimia, Fakultas Sains dan Matematika Universitas Kristen Satya Wacana Salatiga yang telah menjadi wadah serta penyedia sarana selama penelitian berlangsung

\section{Daftar Pustaka}

Affandi., Amri., \& Zultiniar., 2015, Sintesis Hidroksiapatit dari Cangkang Kerang Darah (Anadara granosa) dengan proses Hidrotermal Variasi Rasio $\mathrm{Mol} \mathrm{Ca} / \mathrm{P}$ dan Suhu Sintesis. Jom FTEKNIK Vol. 2, No. 1, Februari.

Agrawal K., Sigh G., Puri D \& Prakash S., 2011, Synthesis and Caracterization of Hydroxyapatite Powder by SolGel Metdod For Biomedical Application, Journal Of Minerals \& Materials Chacterization \& Engineering

Amrina, Q H., 2008, Sintesa Hidroksiapatit dengan Memanfaatkan Limbah Cangkang Telur : Karakterisasi Difraksi Sinar-X dan Scanning Electron Microscopy (SEM). Bogor : Institut Pertanian Bogor.

Chong, J P., Jayne, C B B., Jeanette, K H., David, W., Terry, L M., Karen, E M., 2008, Three Deeply Divided Lineages of The Freshwater Mussel Genus Anodonta in 
Western North America, Conserv.Genet (2008) 9: 1303-1309. DOI: 10.1007/s10592-007-9485-x.

Elkayar A., Elshazly Y \& Assaad M., 2009, Properties Of Hydroxyapatite from Bovine Teeth. Libertas Academica

Ferraz, M P., Monteiro, F J., \& Manuel, C M., 2004, Hydroxyapatite nanoparticles: A review of preparation methodologies. Journal of Applied Biomaterials and Biomechanics, Vol.2:74-80.

Fitri, D K. 2014, Sintesis Hidroksiapatit dari Cangkang Keong Sawah (Bellanya javanica) dengan Metode Basah dan Modifikasi Pori dengan Kitosan. Bogor : Institut Pertanian Bogor.

Gintu, A R., Imelda, W., Marchelia W S., \& Sri Hartini. 2017, Sintesa Biokeramik Hidroksiapatit (HAp) dari Kerabang Telur Ayam Kampung, Ayam Broiler dan Bebek Menggunakan Metode Pengendapan Basa dan Hidrolisis Brushit. Jurnal BIOMA UPGRIS Vol.6 No.2, Oktober 2017 (a).

Gintu, A R., Imelda, W., Marchelia W S., \& Sri Hartini, 2017, Karakterisasi Fisikokimia Biokeramik Campuran HAp-Kitosan, Prosiding SNSE IV UPGRIS 2017 (b).

Khoirudin, M., Yelmida., \& Zultiniar, 2015, Sintesis dan Karakterisasi Hidroksiapatit (HAp) dari Kulit Kerang Darah (Anadara granosa) dengan Proses Hidrotermal. JOM FTEKNIK Vol. 2 No.2.

Mahreni, Endang S., Saeful S., \& Willyam C., 2012, Pembuatan Hidroksiapatit dari Kulit Telur. Pengembangan Teknologi Kimia untuk Pengolahan Sumber Daya Alam Indonesia. Yogyakarta.

Mittal, M., Prakash S., Nath K. S., \& Sapra K. P., 2011, Preparasion Metodology of Hydroxyapatite Powder. Departement of Metallurgical and Materials, Indian Institute of Technology.

Ministry of Forest, Lands and Natural Resourches Operations, Thompson Okanagan Region Resource Management, 2014, Western, Oregon and Floaters Anodonta spp. (kinnerlyi, Oregonensis, and nuttalliana), British Columbia.

Ningsih, R P., Nelly, W., \& Lia, D., 2014, Sintesis Hidroksiapatit dari Cangkang Kerang Darah (Polymesoda erosa) dengan Variasi Waktu Pengadukan. JKK 2014 Vol.3 No.1: 22-26.

Nurmata, D A., Djoni, I R., \& Jan, A. 2014. Optimasi Parameter Waktu Sintering pada Pembuatan Hidroksiapatit Berpori untuk Alikasi Bone Filler pada Kasus Kanker Tulang. Jurnal Fisika dan Terapannya Vol. 2 No. 2

Prabaningtyas, R AJ M Safanti, 2015, Karakterisasi Hidroksiapatit dari Kalsit (PT. Dwi Selo Giri Mas Sidoarjo) sebagai Bone Graft Sintetis Menggunakan XRay Diffractomete (XRD) dan Flourier Transform Infra Red (FTIR). Universitas Jember

Rahmawati, A., Noor, I I., Heru, S; \& Samsudin, A., 2012, Sintesis Hydroxyapatite Berukuran Nano dengan Metode Elektrokimia Menggunakan Pulse Direct Current (PDC) sebagai Bioimplant Tulang dan Gigi, Jurnal Teknik POMITS, Vol.1 No.1: 1-4.

Rahayu, W S., Pri, I U., \& Anis, K. 2011. Validitas Penetapan Kadar Kalsium dalam Sediaan Tablet
Multivitamin Secara Spektrofotometri Ultraviolet Visible. ISSN 1693-359.

Ramli, R. A., Rohana A., Mohamad A. B., \& Sam'an M. M, 2011, Synthesis and Characterisation of Pure Nanoporous Hydroxyapatite. Journal of Physical Science, Vol. 22(1): 25-37.

Sulaeman., Suparto., \& Evianti, 2005, Analisis Kimia Tanah, Tanaman, Air dan Pupuk. Bogor. Balai Penelitian Tanah Departemen Pertanian.

Susanto, E P N., Amiatun., \& Dyah, H., 2014, Sintesis dan Karakterisasi Paduan Kobalt dengan Variasi Cr Melalui Metode Peleburan sebagai Material Implan. Jurnal Fisika dan Terapannya Vol.2 No.2.

Wadu, I., Hartati, S., \& Margareta, N C. 2017. SINTESA DAN PENENTUAN KADAR KALSIUM - FOSFAT HIDROKSIAPATIT (HAp) DARI KERABANG TELUR AYAM. JKPK UNS 2017.

Wadhah, I., Sri, W., \& Darjito, 2014, Sintesis Hidroksiapatit dari Tulang Sapi dengan Metode BasaPengendapan. Kimia Student Journal Vol.1 No.1, pp:92-97.

Wahl DA \& Czernuszka JT. 2006. “ CollagenHydroxyapatite Composites For Hard Tissues Repair “. European Cels and Materials.

Wattanutchariya W \& Whattanapong C., 2014, Characterization of Porous Scaffold from ChitosanGelatin/Hydroksiapatite for Bone Grafting. IMECS. Hongkong.

Windarti, T., \& Yayuk, A., 2006, Pengaruh Konsentrasi $\mathrm{Ca}^{2+}$ dan $\mathrm{PO}_{4}{ }^{3-}$ pada Pembentukan Hidroksiapatit di dalam Matriks Selulosa Bakterial. JSKA Vol.IX No.3.

Yakin, K., 2013, Perhitungan Energi Disosiasi Ca-O dan C-O pada Gugus Fungsi Hidroksiapatit Menggunakan Permodelan Spektroskopi Inframerah. Fakultas Matematika dan Ilmu Pengetahuan Alam, Institut Pertanian Bogor. Skripsi 